\title{
М.В. Веремеенко
}

\section{СУБЪЕКТ МОШЕННИЧЕСТВА В СФЕРЕ ПРЕДПРИНИМАТЕЛЬСКОЙ ДЕЯТЕЛЬНОСТИ}

\begin{abstract}
Рассмотрен вопрос о субъекте нового вида моченничества-моченничества в сфере предпринимательской деятельности (ст. 159.4 УК РФ). Автором указывается на отсутствие в науке единства мнений при определении субъекта данного преступления. Рассматриваются признаки, характеризуюшие субъекта мошенничества в сфере предпринимательской деятельности. Делается вывод об отнесении субъекта моменничества в сфере предпринимательской деятельности к специальным субъектам преступлений.

Ключевые слова: моченничество, предпринимательская деятельность, предприниматель, субъект преступления, специальньй субъект преступления.
\end{abstract}

Федеральным законом от 29 ноября 2012 г. № 207-Ф3 «О внесении изменений в Уголовный кодекс Российской Федерации и отдельные законодательные акты Российской Федерации» Уголовный кодекс Российской Федерации был дополнен новеллами, предусматривающими ответственность за мошеннические деяния, совершаемые в различных сферах деятельности. В частности, уголовный закон был дополнен ст. 159.4 УК РФ, предусматривающей ответственность за мошенничество в сфере предпринимательской деятельности. Указанный вид преступного посягательства представляет собой разновидность общего состава мошенничества, ответственность за которое предусмотрена ст. 159 УК РФ. В связи с чем состав мошенничества в сфере предпринимательской деятельности имеет признаки, характеризующие общий состав мошенничества (ст. 159 УК РФ), с учетом особенностей сферы экономической деятельности, в которой совершается мошенничество, предпринимательская деятельность.

Особого внимания при рассмотрении состава нового вида мошенничества - мошенничества в сфере предпринимательской деятельности - заслуживает субъект данного преступления.

Признаки состава преступления, характеризующие субъекта, немногочисленны. Это связано с принципом равенства всех граждан перед законом [1].

Субъектом преступления признается физическое вменяемое лицо, достигшее установленного законом возраста, виновное в совершении общественно опасного деяния, предусмотренного законом как преступление. Субъект преступления - это не абстрактное юридическое понятие, которое существует вне времени и пространства. Субъект преступления - это человек, живущий и совершающий преступные действия в обществе других людей [2. C. 6].

Учитывая, что ст. 159.4 УК РФ введена в уголовный закон сравнительно недавно, степень изученности состава данного преступления в науке на на- 
стоящий момент невелика. При этом исследователи определяют субъекта мошенничества в сфере предпринимательской деятельности по-разному.

Так, позиция В.М. Лебедева и Н.А. Колоколова сводится к тому, что субъект мошенничества в сфере предпринимательской деятельности - любое дееспособное лицо, достигшее 16-летнего возраста [3, 4].

А.И. Чучаев определяет субъекта преступления, предусмотренного ст. 159.4 УК РФ, как лицо, занимающееся предпринимательской деятельностью: собственник предприятия (организации), руководитель (директор и т.п.), индивидуальный предприниматель, их представители [5].

Указанные точки зрения не в полной мере характеризуют субъекта мошенничества в сфере предпринимательской деятельности. Субъектом мошенничества в сфере предпринимательской деятельности в первую очередь может быть вменяемое физическое лицо, достигшее к моменту совершения преступления возраста шестнадцати лет.

Вопрос о вменяемости либо невменяемости лица должен решаться только по факту совершения конкретного общественно опасного деяния и лишь на момент его совершения. Человек, владеющий нормальными мыслительными и волевыми качествами, в состоянии воспринимать воздействие на его мозг влияний внешнего мира, а следовательно, способен критически подходить к своему поведению, разумно понимать требования, предъявляемые к нему установленными в обществе правилами поведения [6. С. 113-114]. Поэтому вменяемость выступает одним из обязательных свойств человека, в отсутствие которого он не может признаваться субъектом преступления при совершении общественно опасного деяния [7. С. 29].

Способность человека принимать решения, сознавая смысл, значение и последствия совершаемых им действий в конкретной обстановке, определяет ответственность человека за свои поступки, в том числе и общественно опасные [8].

Кроме способности сознавать совершаемое, понимать содержание своих действий, предвидеть их последствия, человек должен иметь возможность управлять своими действиями [7. С. 26].

При установлении минимального возраста для наступления уголовной ответственности законодатель в первую очередь учитывал возможность человека в том или ином возрасте «разбираться в объективной действительности и сознательно руководить своими действиями» [7. С. 126-127].

Проблемным моментом при установлении для субъекта мошенничества в сфере предпринимательской деятельности возраста наступления уголовной ответственности - 16 лет - являлся вопрос о правомерности утверждения именно этого возрастного уровня. Критерием в данном случае служит ст. 27 ГК РФ, регламентирующая в гражданском законодательстве институт эмансипации, согласно которому несовершеннолетний, достигший шестнадцати лет, может быть объявлен полностью дееспособным, если он с согласия родителей, усыновителей, попечителя либо при отсутствии такого согласия по решению суда занимается предпринимательской деятельностью. Это, в свою очередь, предопределяет наличие в составе мошенничества в сфере предпринимательской деятельности такого специального субъекта, как эмансипированный несовершеннолетний предприниматель. 
Специальные субъекты преступления кроме признаков, определяющих их возраст и вменяемость, характеризуются и некоторыми другими.

Если признаки общего субъекта преступления определяются нормами Общей части уголовного законодательства, то признаки специального субъекта, кроме того, предусматриваются и нормами Особенной части.

Специальным субъектом преступления признается физическое вменяемое лицо, виновное в совершении такого общественно опасного деяния, состав которого в качестве обязательного элемента включает те или иные признаки, характеризующие его исполнителя [2. С. 8]. В уголовном законе (ст. 159.4 УК РФ) не содержится прямого указания на то, что субъект мошенничества в сфере предпринимательской деятельности является специальным. Однако следует учитывать, что совершение данного преступного деяния возможно исключительно в сфере предпринимательской деятельности. Это обусловливает наличие у субъекта мошенничества в сфере предпринимательской деятельности кроме общих признаков, относящихся к субъектам любого преступления, и дополнительных признаков, относящихся к сфере преступного посягательства - предпринимательской деятельности.

Само определение понятия предпринимательской деятельности, содержащееся в п. 1 ст. 2 ГК РФ, как самостоятельной, осуществляемой на свой риск деятельности, направленной на систематическое получение прибыли от пользования имуществом, продажи товаров, выполнения работ или оказания услуг лицами, зарегистрированными в этом качестве в установленном законом порядке, указывает на «дополнительные признаки» специального субъекта мошенничества в этой сфере.

Сложившаяся сегодня правоприменительная практика показывает, что лица, совершившие мошенничество в сфере предпринимательской деятельности, признаются таковыми только при наличии у них признаков специального субъекта. Так, согласно п. 1.3.3 Обзора судебной практики по применению Федерального закона от 29.11.2012 № 207-Ф3 и Постановлению Государственной Думы Федерального Собрания РФ от 02.07.2013 № 2559-6 ГД «Об объявлении амнистии» (утв. Президиумом Верховного Суда РФ 04.12.2013) [9] при разрешении ходатайств (представлений) о переквалификации содеянного со ст. 159 УК РФ на ст. 159.4 УК РФ суды учитывали, что виновным в мошенничестве в сфере предпринимательской деятельности признается, в частности, лицо, являющееся индивидуальным предпринимателем, в случае совершения преступления в связи с осуществлением им предпринимательской деятельности и (или) управлением принадлежащим ему имуществом, используемым в целях предпринимательской деятельности, а также члены органов управления коммерческой организации в связи с осуществлением ими полномочий по управлению организацией либо при осуществлении коммерческой организацией предпринимательской деятельности.

Постановлением Хабаровского краевого суда от 24 января 2013 г. было удовлетворено ходатайство М. о переквалификации его действий на ч. 3 ст. 159.4 УК РФ (в редакции Федерального закона от 29 ноября 2012 г. № 207-Ф3).

М. осужден по приговору Железнодорожного районного суда г. Хабаровска от 25 августа 2011 г. по ч. 4 ст. 159 УК РФ. Принимая данное решение, 
суд руководствовался тем, что по приговору М. признан виновным в мошенничестве, т.е. в хищении чужого имущества путем обмана, совершенном лицом с использованием своего служебного положения, в особо крупном размере. Являясь учредителем и директором ООО «Ю.», М. умышленно из корыстных побуждений похитил часть привлеченных для строительства коттеджного поселка денежных средств, принадлежащих участникам долевого строительства, причинив тем самым ущерб в особо крупном размере.

Поскольку М. совершил мошенничество, сопряженное с преднамеренным неисполнением договорных обязательств в сфере предпринимательской деятельности, суд пришел к выводу о переквалификации его действий на ст. 159.4 УК РФ.

В тех случаях, когда судом было установлено и в приговоре отражено, что осужденный на момент совершения мошенничества не являлся индивидуальным предпринимателем или членом органа управления коммерческой организации (отсутствовали доказательства) либо представлялся руководителем несуществующих коммерческих организаций, суды обоснованно отказывали в удовлетворении соответствующих ходатайств (представлений).

Индивидуальными предпринимателями являются физические лица, зарегистрированные в установленном законом порядке и осуществляющие предпринимательскую деятельность без образования юридического лица.

Порядок регистрации индивидуальных предпринимателей и, соответственно, приобретения физическим лицом статуса индивидуального предпринимателя закреплен Федеральным законом от 08.08.2001 № 129-Ф3 (ред. от 21.12.2013) «О государственной регистрации юридических лиц и индивидуальных предпринимателей».

Если же речь идет о лицах, являвшихся членами органа управления коммерческой организации (хозяйственного товарищества и общества, производственного кооператива, государственного и муниципального унитарного предприятия), ибо под последними имеются в виду организации, преследующие извлечение прибыли в качестве основной цели своей деятельности [10], для определения круга лиц, относящихся к членам органов управления коммерческой организации, представляется возможным обратиться к постановлению Пленума Верховного Суда РФ от 16.10.2009 № 19 «О судебной практике по делам о злоупотреблении должностными полномочиями и о превышении должностных полномочий». Согласно этому постановлению к лицам, выполняющим управленческие функции в коммерческой организации, относятся лица, выполняющие функции единоличного исполнительного органа, члены совета директоров или иного коллегиального исполнительного органа, а также лица, постоянно, временно или по специальному полномочию выполняющие организационно-распорядительные или административнохозяйственные функции в этих организациях (например, директор, генеральный директор, член правления акционерного общества, председатель производственного или потребительского кооператива и т.п.) [11]. При этом лица, выполняющие управленческие функции в коммерческой организации, одновременно являются и членами органов управления таковой. Эти понятия равнозначны. 
Пленум Верховного Суда РФ в своем постановлении «О практике применения судами законодательства о мерах пресечения в виде заключения под стражу, домашнего ареста и залога» от 19.12.2013 № 41 разъяснил, что мошенничество, совершенное в сфере предпринимательской деятельности, следует считать таковым, если оно совершено лицом, осуществляющим предпринимательскую деятельность самостоятельно или участвующим в предпринимательской деятельности, осуществляемой юридическим лицом, и эти преступления непосредственно связаны с указанной деятельностью. К таким лицам относятся индивидуальные предприниматели в случае совершения преступления в связи с осуществлением ими предпринимательской деятельности и (или) управлением принадлежащим им имуществом, используемым в целях предпринимательской деятельности, а также члены органов управления коммерческой организации в связи с осуществлением ими полномочий по управлению организацией либо при осуществлении коммерческой организацией предпринимательской деятельности [12].

Таким образом, анализ уголовно-правовой нормы, предусмотренной ст. 159.4 УК РФ, позволяет сделать вывод об отнесении субъекта мошенничества в сфере предпринимательской деятельности к специальным субъектам преступлений.

\section{Лumepamypa}

1. Кудрявцев В.Н. Теоретические основы квалификации преступлений. М.: Гос. изд-во юрид. лит., 1963. $196 \mathrm{c.}$

2. Владимиров В.А., Левицкий Г.А. Субъект преступления по советскому уголовному праву: лекция. М., 1964. 57 с.

3. Комментарий к Уголовному кодексу Российской Федерации (отв. ред. В.М. Лебедев). 13-е изд., перераб. и доп. Юрайт, 2013 // Справочно-правовая система «КонсультантПлюс»: [Электронный ресурс] / Компания «КонсультантПлюс». Послед. обновление 19.02.2014.

4. Колоколов Н.А. Преступления против собственности: комментируем новеллы УК РФ // Мировой судья. 2013. № 1. С. 6-15.

5. Комментарий к Уголовному кодексу Российской Федерации (постатейный) (исправлен, дополнен, переработан) (под ред. д-ра юрид. наук, проф. А.И. Чучаева). «КОНТРАКТ», 2013 // Справочно-правовая система «КонсультантПлюс» [Электронный ресурс] / Компания «КонсультантПлюс». Послед. обновление 19.02.2014.

6. Качурин Д.В. Уголовная ответственность за обман и злоупотребление доверием (мошенничество) в отношении предприятий, организаций и коммерческих структур с различными формами собственности в период рыночных отношений: дис. ... канд. юрид. наук. М., 1996.

7. Орлов В.С. Субъект преступления по советскому уголовному праву. М.: Госюриздат, 1958. $258 \mathrm{c}$.

8. Пионтковский А.А. Учение о преступлении. М., 1961. 665 с.

9. Обзор судебной практики по применению Федерального закона от 29.11.2012 № 207-Ф3 и Постановления Государственной Думы Федерального Собрания РФ от 02.07.2013 № 2559-6 ГД «Об объявлении амнистии» (утв. Президиумом Верховного Суда РФ 04.12.2013) // Справочно-правовая система «КонсультантПлюс» [Электронный ресурс] / Компания «КонсультантПлюс». Послед. обновление 19.02.2014.

10. Приказ Росстата от 01.10.2007 № 150 «О Методических указаниях по расчету основного вида деятельности хозяйствующих субъектов на основе Общероссийского классификатора видов экономической деятельности (ОКВЭД) для формирования сводной официальной статистической информации» (вместе с «Методическими указаниями по расчету основного вида экономической деятельности хозяйствующих субъектов на основе Общероссийского классификатора видов экономической деятельности (ОКВЭД) для формирования сводной официальной 
статистической информации») // Справочно-правовая система «КонсультантПлюс» [Электронный ресурс] / Компания «КонсультантПлюс». Послед. обновление 19.02.2014.

11. Постановление Пленума Верховного Суда РФ от 16.10.2009 № 19 «О судебной практике по делам о злоупотреблении должностными полномочиями и о превышении должностных полномочий» // Российская газета. 2009. 30 окт.

12. Постановление Пленума Верховного Суда РФ от 19.12.2013 № 41 «О практике применения судами законодательства о мерах пресечения в виде заключения под стражу, домашнего ареста и залога» // Российская газета. 2013. 27 дек.

\section{Veremeenko Mikhail $V$. Tomsk Law Agency Ltd (Tomsk, Russian Federation)}

THE SUBJECT OF FRAUD IN ENTREPRENEURIAL ACTIVITY.

Keywords: fraud, entrepreneurial activity, entrepreneur, subject of crime, special subject of crime.

The article deals with the subject of fraud in entrepreneurial activity (Article 159.4 of the Criminal Code of the Russian Federation). The author presents the viewpoints of some scientists on the subject of fraud in entrepreneurial activity, emphasizes the lack of the unanimity of opinions on this crime and considers the characteristics of the subject of fraud in entrepreneurial activity.

A sane person, who has committed a crime at the age of 16 or over, can be the subject of fraud in entrepreneurial activity. Besides age and insanity, some special subjects of crime are characterized by other criteria. Russian criminal law (Article 159.4 of the Criminal Code of the Russian Federation) does not imply that the subject of fraud in entrepreneurial activity is a special one. Taking into account that the commission of the above crime is possible only in entrepreneurial activity, the subject of fraud in entrepreneurial activity has some additional characteristics of this sphere of infringement. The author refers to the concept of entrepreneurial activity in Item 1, Article 2 of the Civil Code of the Russian Federation according to which: entrepreneurial activity is an independent, conducted at one's risk activity which is aimed at a systematic gaining of profit from the use of property, sales, work or rendered services by the legally registered entrepreneurs. The definition of the concept "entrepreneurial activity" emphasizes "additional characteristics" of the special subject of fraud in this sphere.

Any individual entrepreneur can be found guilty of fraud in entrepreneurial activity if he has committed it within the frame of his entrepreneurial activity and (or) administration of his property. Those members of commercial organization management bodies who are involved in administration or in entrepreneurial activity can also be found guilty of fraud. This conclusion is supported by the current law enforcement practice.

The author determines the notions of both an individual entrepreneur and a person -member of a commercial organization management body. The conclusion about the reference of the subject of fraud in entrepreneurial activity to the group of special subjects of crime is done on the basis of the analysis of Article 159.4 of the Criminal Code of the Russian Federation and established law enforcement practice.

\section{References}

1. Kudryavtsev V.N. Teoreticheskie osnovy kvalifikatsii prestupleniy [The theoretical foundations of crime qualification]. Moscow: Gosyurizdat Publ., 1963. 196 p.

2. Vladimirov V.A., Levitskiy G.A. Sub"ekt prestupleniya po sovetskomu ugolovnomu pravu [The subject of crime in the Soviet criminal law]. Moscow: Gosyurizdat Publ., 1964. 57 p.

3. Lebedev V.M. (ed.) Kommentariy k Ugolovnomu kodeksu Rossiyskoy Federatsii [The commentary on the Criminal Code of the Russian Federation]. Moscow: Yurayt Publ., 2013. Available at: http://base.consultant.ru/cons/cgi/online.cgi?req $=$ doc; base $=\mathrm{CMB} ; \mathrm{n}=17312 ; \mathrm{dst}=106981$. (Accessed: 19th February 2014).

4. Kolokolov N.A. Crimes against Ownership: Commenting Novellas of the Criminal Code of the RF. Mirovoy sud'ya, 2013, no. 1, pp. 6-15. (In Russian).

5. Chuchaev A.I. (ed.) Kommentariy k Ugolovnomu kodeksu Rossiyskoy Federatsii [The commentary to the Criminal Code of the Russian Federation]. Moscow: KONTRAKT Publ., 2013. Available at: http://base.consultant.ru/cons/cgi/online.cgi?req=doc; base=CMB; $n=17380 ; \mathrm{dst}=103826$. (Accessed: 19th February 2014).

6. Kachurin D.V. Ugolovnaya otvetstvennost' za obman i zloupotreblenie doveriem (moshennichestvo) $v$ otnoshenii predpriyatiy, organizatsiy $i$ kommercheskikh struktur s razlichnymi formami 
sobstvennosti v period rynochnykh otnosheniy: dis. kand. yurid. nauk [Criminal liability for fraud and breach of trust (fraud) in relation to companies, organizations and businesses with various forms of ownership in the period of market relations. Law Cand. Diss.]. Moscow, 1996.

7. Orlov V.S. Sub"ekt prestupleniya po sovetskomu ugolovnomu pravu [The subject of crime in the Soviet criminal law]. Moscow: Gosyurizdat Publ., 1958. 258 p.

8. Piontkovskiy A.A. Uchenie o prestuplenii [The doctrine of the crime]. Moscow: Gosyurizdat Publ., 1961. 665 p.

9. The review of judicial practice of the application of the Federal Law no. № 207-FZ of November 29, 2012, and the Resolution no. 2559-6 DG "On Amnesty" of the State Duma of the Federal Assembly of the Russian Federation of July 2, 2013 (approved by the Presidium of the Supreme Court of December 4, 2013). Available at: http://base.consultant.ru/cons/cgi/ online.cgi?req= doc;base= ARB; $\mathrm{n}=366996$; dst=100065. (Accessed: 19th February 2014). (In Russian).

10. Order no. 150 of the Federal State Statistics Service of October 1, 2007 "On Guidelines on the calculation of the principal activity of business entities based on the North American Industry Classification System (NACE) to generate a summary of official statistical information" (with the "Guidelines for the calculation of the main economic activity business entities based on North American Industry Classification System (NACE) to form the official statistical information"). Available at: http://www.consultant.ru/document/cons_doc_LAW_82203/. (Accessed: 19th February 2014). (In Russian).

11. Postanovlenie Plenuma Verkhovnogo Suda RF ot 16.10.2009 № 19 "O sudebnoy praktike po delam o zloupotreblenii dolzhnostnymi polnomochiyami i o prevyshenii dolzhnostnykh polnomochiy" [Resolution no. 19 of the Plenum of the Supreme Court of October 16, 2009 "On judicial practice in cases of abuse of power and abuse of office"]. Rossiyskaya gazeta, 2009, 30th October.

12. Postanovlenie Plenuma Verkhovnogo Suda RF ot 19.12.2013 № 41 "O praktike primeneniya sudami zakonodatel'stva o merakh presecheniya $\mathrm{v}$ vide zaklyucheniya pod strazhu, domashnego aresta i zaloga" [Resolution no. 41 of the Plenum of the Supreme Court of December 19, 2013 "On the application of the legislation on preventive measures in the form of detention, house arrest and bail by the courts"]. Rossiyskaya gazeta, 2013, 27th December. 